Does Job Satisfaction, Fair Treatment, and Cooperativeness Influence the Whistleblowing Practice in Malaysian Government Linked Companies?

\author{
Jamaliah Said \\ Accounting Research Institute \\ Universiti Teknologi MARA \\ Shah Alam, Malaysia \\ Email: jamaliah533@salam.uitm.edu.my \\ Md. Mahmudul Alam* \\ School of Economics, Finance and Banking \\ Universiti Utara Malaysia \\ Sintok, Malaysia \\ E-mail: rony000@gmail.com \\ Dar Irna Bt Mohamed \\ Faculty of Accountancy \\ Universiti Teknologi MARA \\ Shah Alam, Malaysia \\ E-mail: darirnamohamed@yahoo.com \\ Marhamah Rafidi \\ Accounting Research Institute \\ Universiti Teknologi MARA \\ Shah Alam, Malaysia \\ Email: marhamahrafidi89@gmail.com \\ *Corresponding author \\ Citation Reference:
}

Said, J., Alam, M.M., Irna, D., and Rafidi, M. 2017. Does Job Satisfaction, Fair Treatment, and Cooperativeness Influence the Whistleblowing Practice in Malaysian Government Linked Companies?. Asia-Pacific Journal of Business Administration, 9(3): 220-131. (online) http://www.emeraldinsight.com/doi/pdfplus/10.1108/APJBA$\underline{06-2017-0053}$

This is a pre-publication copy.

The published article is copyrighted by the publisher of the journal. 


\title{
Does Job Satisfaction, Fair Treatment, and Cooperativeness Influence the Whistleblowing Practice in Malaysian Government Linked Companies?
}

\begin{abstract}
Purpose: Whistleblowing is an important factor in preventing corruption and fraud in organizations. There is a law to promote whistleblowing practices, but the negative subsequent effect of whistleblowing demotivates the reporting of unethical behaviours. Thus, it is important to identify the factors that motivate an employee to exercise whistleblowing in an organization. Therefore, this study aims to examine whether the personal factor of job satisfaction and organizational factors such as fair treatment as well as cooperativeness contribute to the whistleblowing practice in an organization.

Design/methodology/approach: This study collected primary data based on a questionnaire survey from 73 respondents of the seven top most GLCs in Malaysia. The data are analyzed using descriptive statistics, factor analysis, and cross-sectional regression.

Findings: The findings of the study reveal that only fair treatment is statistically significant and positively related to the whistleblowing practice. The findings imply that if employees perceive that the organization provides fair treatment in terms of career advancement, awards, training, performance appraisal, job assignment, and pay increases, they would tend to report wrongdoing activities to protect the image of the organization.

Practical implications: The findings of the study will help the policy makers to ensure better working environment and accountability in the public sector of Malaysia and other similar countries.

Originality/value: This is an original study based on primary data to examine the current practices of whistleblowing and its relationship with the practices of job satisfaction, fair treatment, and cooperativeness in the government linked companies of Malaysia.
\end{abstract}

Keywords: Government Linked Company (GLC); Job Satisfaction; Fair Treatment; Cooperativeness; Whistleblowing practice

\section{Introduction}

Whistleblowing can be defined as "the voluntary release of information, as a moral protest, by a member of an organization about illegal or immoral conduct in the organization that is opposed to the public interest" (Chiu, 2003). Near and Miceli (1985) define whistleblowing as "the disclosure by organization members on illegal, or illegitimate practices to persons" (Read \& Rama, 2003). Ponemon and Gabhart (1994) state that "whistle-blowing can play an essential role as a defective control if an organization explicitly incorporates reporting mechanism that discloses incident of wrongdoing.

As the number of fraud cases continues to rise sharply over the years due to failures in reporting activities deemed illegal, unethical, or not correct within an organization (Said, Alam, \& Khalid, 2016; Cecilia, 2013; Chiu, 2003), whistleblowing may mitigate bigger losses, as the longer the fraud goes undiscovered, the bigger the losses would be (Taylor \& Curtis, 2010; Cecilia, 2013; Ghani, Galbreath, \& Evans, 2012). The decision to whistleblow is considered an expression of rebellion especially in public organizations (Cecilia, 2013). It involves conflicting values between loyalty to the organization and accountability to the public (Johnson, 2003). Glazer (1987) states that whistleblowers are "ethical resisters in government" who "disobey their superiors" when they bring attention to issues. The act of whistleblowing is considered a political act when it involves public servants. 
There are some legal protections available for whistleblowers. Sarbanes-Oxley Act of 2002 (SOX) is one of the acts that has been introduced as a result of financial scandals. One of the concerns addressed by SOX is the protection of whistleblowers. Section 806 of the Act states that a company is prohibited from retaliating against an employee after the disclosure of misconduct in the organization. This should increase the effectiveness of whistleblowing activities since it has been proven that employees are reluctant to engage in whistleblowing because of the subsequent effects (Moberly, 2006).

However, in reality there are many reasons why whistleblowing does not happen widely. Although whistleblowing gives a spark to the monitoring control, it usually brings undesirable consequences to the whistleblower (Chiu, 2003). Some of them will lose their jobs, receive threats of revenge, experience social isolation at work, face retaliation from the management, and end up getting an unfair treatment from the company. It has been reported that $90 \%$ of whistleblowers lose their jobs or are demoted (Chiu, 2003). Such after-effects from reporting misconduct deter many employees from reporting corporate misconduct.

Many organizations adopt a whistleblowing policy as one of the internal control mechanisms to improve the efficiency of the monitoring process related to fraud and corruption (PWC, 2014). However, past studies have proven that the whistleblower tends to face consequences in the future; this is one of the factors that lead to the failure of the whistleblowing mechanism (Ngui, 2005; Seifert, 2006). Previous studies have focused on the effects of financial rewards associated with the whistleblowing activity. Stikeleather (2001) found that employers can support whistleblowing and earn a higher pay-off by offering workers with explicit financial rewards for whistleblowing, but this eventually decreases the workers' non-financial motivation to blow the whistle. Cecilia (2013) used a mixed method approach to examine the relationship between individual and organizational elements that encourage employees to report wrongdoing in the civil system. Lipman (2012) believed that there are ineffective whistleblowing programmes conducted by organizations. The organizational environment contributes to the effectiveness of the whistleblowing policy. According to a PWC report (2014), organizations have an effective whistleblowing system but they do not implement the system in real life. The effective system is only on paper but not in practice.

Previous studies have discussed the factors that encourage employees to engage in whistleblowing activities. Seifert (2006) found that a fair whistleblowing procedure has a positive effect on the likelihood of reporting misconduct by employees. The fair environment includes treatment by management, interaction with management regarding whistleblowing as well as the whistleblowing procedure (Seifert, 2006). It is viewed that fair environment is associated with a higher whistleblowing practice. Extensive studies have examined both individual and organizational factors on whistleblowing practices (Rice, 2015; Cecilia, 2013; Alleyne, 2010).

Currently, Asian countries are still in the early stage of the whistleblowing implementation compared to some developed countries (Park, Rehg, \& Lee, 2005). Negative implication of whistleblowing is one of the possible reasons that results in Asian countries being less aggressive in embracing the whistleblowing action (Ghani, Galbreath, \& Evans, 2012). Meanwhile in Malaysia, whistleblowing is still in its introductory stage and is a lessfavoured medium to report wrongdoing in organizations (Ngui, 2005). 
In Malaysia, the role of whistleblowing as an internal control mechanism is only regarded by the statutory authorities (Anwar, 2003). The first whistleblowing law was introduced in 2003 under the Securities Industry Act 2003. Subsequently, the Malaysian government has encouraged all organizations to support the whistleblowing law in return with protection to move towards a corruption-free country (Hassan, 2006). There are issues in which GLCs are involved in fraud and corruption. The GLC Transformation Programme (GTP) has a major role in nation-building and the strategic execution of structural economic changes. While the GTP promises increased transparency, questions are being asked as to whether the GLC has actually driven the economy to deliver such an assurance. As an example related to the whistleblower website, various postings have been posted with regards to the activities of one of the Malaysian GLCs, 1Malaysia Development Berhad (1MDB) which to date remain unanswered. Some of the questions are related to whether there has been a falsification of documents by $1 \mathrm{MDB}^{1}$. Therefore, the involvement of the whistleblowing practice is of utmost importance especially in the internal aspect, as it will reduce fraud incidents.

In Malaysia, GLCs are known as the main providers of utilities, airlines, airport, public transportation, water and sewerage, and financial services. Some of them are also involved in the automotive, plantation, and construction industries. These organizations employ around 5\% (about 400,000 employees) of the national workforce and account for approximately $36 \%$ of the Malaysian Stock Exchange market capitalization (Abdullah, 2005). By considering the significance of the GLC to the economy, an understanding of the whistleblowing practice in the GLC organizations is indeed significant, and thus requires an intensive research.

In Malaysia, although the whistleblower protection act has been established to protect the informer, the actual implementation remains low and the research conducted is limited. Even though the whistleblowing act protects the whistleblower's right, many people are still indecisive due to personal and organizational factors. This study aims to investigate the whistleblowing behaviour in Government Linked Companies by exploring the individual and organizational characteristics that influence the employees' behaviour to be involved in whistleblowing. Evaluation of both individual and organizational factors will help an organization to understand the factors that improve the effectiveness of the whistleblowing system and simultaneously reduce the likelihood of fraud and corruption.

\section{Literature Review and Hypotheses Development}

\subsection{Job Satisfaction and the Whistleblowing Practice}

Alleyne (2010) found that individual factors such as attitude, commitment, personal responsibility, and behavioural control significantly influence people to whistleblow. Individual satisfaction will increase the likelihood of certain behaviours such as reporting wrongdoing (Miceli \& Near, 1992). Employees who are satisfied with their work, environment, and payment are inclined to protect their jobs as well as their organization (Cecilia, 2013). Besides, other researches have proposed that highly satisfied workers are less likely to engage in whistleblowing. This is because the environment shapes the employees to be efficient and follow ethical standards, thus reducing the occurrence of fraud. Job satisfaction is significantly associated with the intention to whistleblow (Cecilia, 2013).

\footnotetext{
${ }^{1}$ Retrieved from http://www.freemalaysiatoday.com
} 
Meanwhile, Miceli and Near (2005) suggest that job satisfaction affects whistleblowing since job satisfaction keeps changing in response to a specific job situation, and it is deduced that whistleblowers are less satisfied with their jobs than the non-reporting observers. For example, an observer of wrongdoing with a higher negative disposition is less satisfied than one with a higher positive disposition, so he/she is likely to report the wrongdoing. Another research suggests that job satisfaction is positively related to whistleblowing (Viswesvaran Deshpande \& Joseph, 1998). Job satisfaction is higher when supervisors endorse an ethical working behaviour (Viswesvaran Deshpande \& Joseph 1998). The findings reveal that individuals who perceive top management as being supportive will be more satisfied with their jobs, reflecting their ethical behaviour.

There is a mixed result on the relationship between job satisfaction and the whistleblowing practice. Some studies have found that highly satisfied workers are less likely to engage in pro-social behaviour (Shawver \& Clement, 2008; Sims \& Keenan, 1998; Vakola \& Bouradas, 2005). A study conducted by Cecilia on 36,926 employees in 24 federal agencies in the US found a negative relationship between job satisfaction and the likelihood to whistleblow in the federal government (Cecilia, 2013). The negative association is due to job satisfaction, thus reducing the action that will affect the organizational image. In the context of GLCs, an act of reporting misconduct is believed as an expression of rebellion (Cecilia, 2013), which reflects disloyalty to the organization (Johnson, 2003) and an indication of disobedience to the superiors (Glazer,1987). Therefore, it is proposed that:

H1: There is a significant negative relationship between job satisfaction and the whistleblowing practice.

\subsection{Fair Treatment and the Whistleblowing Practice}

Fairness is a term that is often interchangeably used with justice by social scientists. Procedural and distributive justice is closely associated with employee motivation and goaloriented behaviour (Kanungo, 1982; Lawler, 1992; Lodahl \& Kejnar, 1965; Paullay, Alliger, $\&$ Stone, 1994). Previous research has suggested that fair treatment within the workplace will increase the report of wrongdoing in the organization (Rothschild \& Miethe, 1999; Near, Dworkin, \& Miceli, 1993; Seifert, 2006; Trevino \& Weaver, 2001). On the other hand, other studies which focus on civil servants disclose that a variety of organizational and job-related factors, such as fairness, do influence employees' motivation and their involvement in work. The working environment will stimulate the employees' behaviour, thus influencing the way they react towards their organization. Besides, fairness in reporting procedures is more favourable and there will be less retaliation for those involved in whistleblowing (Near, Dworkin, \& Miceli, 1993). The perception of having a fair treatment will make the employees comfortable to talk to the management regarding the matter that is against the organizational goal. Trevino and Weaver (2001) also assessed whether the employees are more willing to help the organization in dealing with problems that will affect the organization's achievement and report ethical problems to the management. The findings reveal that a perceived fair treatment is a significant predictor of the number of reports lodged to the management.

A study conducted by Murray (2006) shows that the inclination to report a wrongdoing is positively related to procedural justice, interactional justice, role responsibility, and issue severity. Justice or fairness involves all aspects in the organization, 
which are the treatment given by the organization, procedures, colleagues, and others. The fair treatment provided by the management results in a sense of belonging by the employees to the company. The feeling of responsibility leads the employees to protect the company's image and reputation from being tarnished by malpractice (Trevino \& Weaver, 2001). In addition, fairness in the context of whistleblowing procedures and treatment will enhance the employees' willingness to engage in the whistleblowing practice. Retaliation is one of the factors that hinders the employees from reporting a misconduct. Cecilia (2013), however, discovers an opposite finding, in which there is a negative relationship between fair treatment and report of wrongdoing. By having a fair and just treatment from the management and colleagues, employees are keen to report any wrongdoing. Therefore, it is proposed that:

H2: There is a significant positive relationship between fair treatment and the whistleblowing practice.

\subsection{Cooperativeness and the Whistleblowing Practice}

Rothwell and Baldwin (2006) state that a cooperative work environment can be found in the organizational culture, in which teamwork and group cohesiveness prevail in the organizational decision-making. Cooperation occurs when the employees in the organization have a strong relationship to work together and achieve their goals. Cooperativeness and a flexible working environment will improve productivity and workers will be more engaged in their work. The balance demands more work and other aspects of the workers' life in contributing towards a cooperative and flexible environment. In addition, research has proven that a cooperative and flexible work arrangement reduces the stress level and boosts the employees' satisfaction in their jobs.

A cooperative environment will enhance the decision-making process (Rothwell \& Baldwin, 2006). Research also proves that a team's mutual interest and cooperation are significantly related to the willingness to report misconduct. Besides, the employees are more willing to discuss with the management regarding the misconduct done by their colleagues (Rothwell \& Baldwin, 2007). In line with previous studies, Vadera, Aguilera, and Caza (2009) also found similar findings, in which a friendly and cooperative team is more likely to engage in a whistleblowing practice.

In contrast, some researchers found a different association, in which a more cooperative and flexible working environment would reduce the tendency of employees from engaging in a pro-social behaviour. A respectful and cooperative environment provides a better communication medium and procedures when a wrongdoing is observed, thus reducing the implementation of the whistleblowing practice (Cecilia, 2013). However, this result was focused on federal employees who have a different social and working environment compared to non-federal employees. In the study, Cecilia also explains that the cooperativeness in the federal working environment are perceived to contribute to less wrongdoing (Cecilia, 2013). A few federal employees feel responsible for reporting wrongdoing as the working environment itself operates as a diffuser for intervention. Moreover, the cooperative and flexible environment with good communication and commitment would encourage the employees to handle the misconduct internally due to an excellent teamwork. Therefore, it is proposed that:

H3: There is a significant positive relationship between cooperativeness and the whistleblowing practice. 


\section{Methodology}

\subsection{Sampling and Data Collection}

Data for the study were collected based on a random survey from 7 out of 47 GLCs in Malaysia. The selected companies are UMW Holding Bhd., TH Plantation Bhd., TH Heavy Engineering Bhd., Tenaga Nasional Bhd., Sime Darby Bhd., CIMB Group Bhd., and Axiata Group Bhd. The survey questionnaires were distributed to 120 individuals from different positions in the 7 selected GLCs, and a total of 73 sets of questionnaires were collected from the respondents.

\subsection{Determinants of Variable}

This research used the conceptual framework created by Miceli, Near, and Dworkin (2008) to answer the issues regarding individual and organizational elements that encourage the whistleblowing practice. This study used ten parameters to measure practices of whistleblowing, seven factors to measure job satisfaction and fair treatment, and eight factors to measure cooperativeness. The list of the items/parameters is presented in the appendix. A seven-point Likert-type rating scale ranging from 1 (strongly disagree) to 7 (strongly agree) was used in the questionnaire.

\subsection{Model and Statistical Test}

The data are analyzed using descriptive statistics, factor analysis, and cross-sectional regression. Initially, validity of the data is tested through several standard diagnostic procedures - the adequacy of data is tested using the Kaiser-Meyer-Olkin test; the normality of data is tested using the skewness and kurtosis analysis; and the homoscedasticity of data is tested using the F-test and Bartlett Sphericity test. Then, a correlation analysis is carried out to check the multicollinearity problem. Finally, the reliability of the data is tested by using the Cronbach's alpha test.

\section{Results and Findings}

\subsection{Demographic Information}

Among the respondents, approximately $50.7 \%$ are female (Table 1). Most of the respondents are in the 26 to 30 years age group, which comprised approximately $48 \%$ of the total respondents. Nearly all of the respondents have at least a bachelor's degree. Approximately $40 \%$ of the respondents have been working for 1 to 3 years, whereas $30 \%$ of the respondents have been working for 4 to 5 years. As for salary ranges, $45 \%$ of the respondents stated that their salary is within RM3000 to RM4000 range and 31\% mentioned that their salary is within RM2000 to RM3000 range.

Table 1: Demographic Profiles of the Respondents

\begin{tabular}{llrr}
\hline \multirow{2}{*}{ Type } & \multicolumn{1}{c}{ Description } & Frequency & Percentage (\%) \\
\hline \multirow{2}{*}{ Gender } & Male & 37 & 50.7 \\
& Female & 36 & 49.3 \\
\hline \multirow{3}{*}{ Age } & 20 to 25 & 7 & 9.6 \\
& 26 to 30 & 35 & 47.9 \\
& 31 to 35 & 23 & 31.5
\end{tabular}




\begin{tabular}{llrr} 
& 36 to 40 & 7 & 9.6 \\
& 51 above & 1 & 1.4 \\
\hline \multirow{3}{*}{ Education } & Diploma & 13 & 17.8 \\
& Bachelor & 58 & 79.5 \\
& Master & 2 & 2.7 \\
\hline \multirow{4}{*}{ Period of Service } & Less than 1 year & 5 & 6.8 \\
& 1 to 3 years & 29 & 39.7 \\
& 4 to 5 years & 22 & 30.1 \\
& 5 years and above & 17 & 23.3 \\
\hline \multirow{4}{*}{ Monthly salary } & 1000 to 2000 & 3 & 4.1 \\
(RM) & 2001 to 3000 & 23 & 31.5 \\
& 3001 to 4000 & 33 & 45.2 \\
& 4001 to 5000 & 9 & 12.3 \\
& 5001 and above & 5 & 6.8 \\
\hline
\end{tabular}

\subsection{Correlation Analysis}

Correlation examines the relationship between two variables in a linear fashion (Coakes, Steed, \& Price, 2008). This analysis helps to identify whether one variable is related to another. Prior to testing the model, the correlation analysis is performed to examine the relationship among the variables. For this study, a Pearson Correlation test is used to ascertain whether there are any multicollinearity problems occurring. The two variables are considered highly correlated to each other and explain the dependent variable, which will cause a multicollinearity problem if the values of coefficient are 0.8 or 0.9 , and above (Field, 2000).

Table 2 shows the summary of the results when the bivariate analysis is done to test the correlation between one variable to another. The statistical results show that the correlation values among the variables range between 0.25 and 0.69 . This indicates that there is no multicollinearity problem among the variables since none of the correlation is more than 0.8. The results also show statistically significant and positive relationships among the variables, but the whistleblowing practice shows a low level of correlations with others.

Table 2: Correlation Analysis

\begin{tabular}{lllll}
\hline & $\begin{array}{l}\text { Job } \\
\text { Satisfaction }\end{array}$ & $\begin{array}{l}\text { Fair } \\
\text { Treatment }\end{array}$ & Cooperativeness & $\begin{array}{l}\text { Whistleblowing } \\
\text { Practice }\end{array}$ \\
\cline { 2 - 5 } Job Satisfaction & 1 & $.647^{* *}$ & $.698^{* * *}$ & $.258^{*}$ \\
Fair Treatment & & 1 & $.629^{* *}$ & $.384^{* *}$ \\
Cooperativeness & & 1 & $.322^{* *}$ \\
Whistleblowing Practice & & & & 1 \\
\hline
\end{tabular}

$*, * *$ indicates significance at the $10 \%$ and $5 \%$ levels

\subsection{Regression Analysis}

Based on the result, the regression stands statistically at a $5 \%(\mathrm{p}<0.05)$ level that also indicates the homoscedasticity or homogeneity of variances, but the $\mathrm{R}^{2}$ value indicates that only $16 \%$ of the whistleblowing practice can be explained by this model (Table 3 ).

Table 3: Regression Analysis 


\begin{tabular}{lllll}
\hline Variables & $\begin{array}{l}\text { Standard } \\
\text { Coefficient }\end{array}$ & Std. Error & t-statistic & p-value \\
\hline Constant & 20.265 & 8.497 & 2.385 & .020 \\
Job Satisfaction & -.124 & .310 & -.401 & .690 \\
Fair Treatment & .614 & .292 & 2.105 & .039 \\
Cooperativeness & .277 & .272 & 1.019 & .312 \\
\hline $\mathrm{R}$ & & & .400 & \\
$\mathrm{R}^{2}$ (Adjusted $\mathrm{R}^{2}$ ) & & .160 & \\
Adjusted $\mathrm{R}$ Square & & .124 & \\
Std. Error of the Estimate & & 9.866 & \\
Significance at $\mathrm{p}<0.05$ & & & \\
\hline
\end{tabular}

The regression output depicts that there is a statistically significant and positive relationship between the whistleblowing practice and fair treatment. Hence, this result indicates that fair treatment in regards to career advancement, awards, training, performance appraisal, job assignment, discipline, and pay has a significant positive relationship to the whistleblowing practice. This is similar to the studies conducted by Near, Dworkin, and Miceli (1993), Rothschild and Miethe (1999), Trevino and Weaver (2001), and Seifert (2006). They found that fair treatment in the workplace increases the report of wrongdoing. The fairness in the organization will be the determinant factor for employees to be more open in reporting any misconduct to the management (Rothschild \& Miethe, 1999). Besides, fair treatment from the management affects the employee perceptions where they believe they own something in the organization (Trevino \& Weaver, 2001). In contrast with another study conducted by Cecilia (2013), fairness in the organization reduces the report of wrongdoing. The difference in the findings may be due to different working environments because the study conducted by Cecilia was done among federal employees.

The regression output shows a negative but statistically insignificant relationship between the whistleblowing practice and job satisfaction. This result is similar to the findings from previous studies conducted by Sims and Keenan (1998), in which they failed to find any relationship between job satisfaction and whistleblowing. Similarly, the study done by Shawver and Clement (2008) found that accounting professionals with higher satisfaction are less likely to engage in a whistleblowing activity. When the employees are satisfied with the task given and the working environment, they are less likely to report any wrongdoing in the organization.

The regression output shows a positive but statistically insignificant relationship between the whistleblowing practice and cooperativeness. The finding is in line with a previous study conducted by Cecilia (2013), where it is revealed that cooperativeness and a flexible environment has no effect on the whistleblowing practice. A cooperative environment induces the workers to neglect any wrongdoings that occur in the organization. They tend to accept any misconduct since they are familiar with the situations. This is different from a study conducted by Vadera, Aguilera, and Caza (2009), in which they revealed that strong ethics and a friendly environment increase the likelihood of the whistleblowing practice.

\subsection{Diagnostic Test}

In order to ensure the data is normally distributed, the study examines the skewness and kurtosis of the data. According to Tabachnick and Fidell (2001), the data is considered normal if the value of skewness and kurtosis is between -2 to +2 . Based on Table 4 , the 
skewness for all variables show a normal distribution as all the values are between -2 to +2 (Table 4). In addition, the kurtosis of the data for all variables shows that the data distribution is normal.

Table 4: Test of Normality \& Reliability

\begin{tabular}{l|c|c|c|c|c}
\hline & Mean & $\begin{array}{c}\text { Std. } \\
\text { deviation }\end{array}$ & Skewness & Kurtosis & $\begin{array}{c}\text { Cronbach's } \\
\text { Alpha }\end{array}$ \\
\cline { 2 - 6 } Job Satisfaction & 37.07 & 5.645 & .246 & -.720 & .928 \\
Fair Treatment & 34.77 & 5.532 & -.489 & -.190 & .923 \\
Cooperativeness & 39.12 & 6.307 & .056 & -.561 & .918 \\
Whistleblowing Practice & 47.86 & 10.539 & .058 & -.800 & .932 \\
\hline
\end{tabular}

Reliability analysis looks at the internal consistency and stability of the measuring instrument. Cronbach's alpha coefficient is commonly used as the internal consistency indicator. The ideal value of Cronbach's alpha coefficient differs among various studies. Nunnally (1978, p.226) suggests a modest reliability ranging between 0.5 and 0.6 would suffice for an initial study. Loewenthal (2004) mentions the value of 0.6 could be acceptable. Hair, Black, Babin, Anderson, and Tatham (2010) mention that the generally agreed lower limit for Cronbach's alpha may decrease to 0.60 in an exploratory research. Pallant (2007) mentions it should be above 0.700. The results of the Cronbach's Alpha for all of the variables in this study are more than 0.9 , which means all the statements are reliable (Table 4).

Moreover, by using the varimax rotations, an exploratory factor analysis is performed to understand the correlations structure of each variable and the sampling adequacy. The factor analysis provides the consistency of these variables for the measurement of job satisfaction, fair treatment, cooperativeness, and the whistleblowing practice. The factor loadings for all the variables are more than 0.6 (Appendix). The Kaiser-Meyer-Olkin coefficient for these dataset is 0.987 for job satisfaction, 0.91 for fair treatment, 0.826 for cooperativeness, and 0.847 for the whistleblowing practice, indicating that the data could be used to proceed with the exploratory factor analysis (Hair, Black, Babin, Anderson, \& Tatham, 2010).

In addition, to test the homoscedasticity or homogeneity of variances, the Bartlett Sphericity test is conducted where the value for job satisfaction (Chi-square $=380$, $\mathrm{p}<.000001$ ), fair treatment (Chi-square $=352, \mathrm{p}<.000001$ ), cooperativeness (Chi-square $=429$, $\mathrm{p}<.000001$ ), and the whistleblowing practice (Chi-square $=673, \mathrm{p}<.000001$ ) are noted to be statistically significant.

\section{Conclusion}

Whistleblowing is actually the act of people who believe that the public interest is important so they get involved in reporting the wrongdoing. This study is carried out to examine the relationship between an individual factor that is job satisfaction and organizational factors that are fair treatment and cooperativeness towards the whistleblowing practice in government linked companies (GLCs) in Malaysia.

This study found that fair treatment has a statistically significant and positive relationship with the whistleblowing practice, but job satisfaction and cooperativeness have no statistically significant relationship with the whistleblowing practice. However, there are 
some limitations in this study that need to be taken care of in future researches by considering a larger sample size and different groups of samples.

Whistleblowing and fraud are highlighted in numerous academic studies nowadays. The occurrence of fraud can be reduced by the implementation of the whistleblowing practice within the organizational culture. The findings would be useful for many parties especially the regulatory authorities, management, and those who are responsible for persuading the employees to be involved in reporting wrongdoing. Besides that, the management in each organization should be more aware of the environment that will enhance the participation of employees to report wrongdoings. In addition, the management also needs to give fair treatment to all the employees without any discrimination. The fairness perceived by the workers will change their attitudes and thus lead them to be involved in extra pro-social behaviors.

\section{Reference}

Abdullah, A. (2005). The GLC transformation program. Retrieved from speech presented on 29 July, Kuala Lumpur Convention Centre, Kuala Lumpur, Malaysia. http:// www.pcg.gov.my.

Alleyne, P.A. (2010). The Influence of Individual, Team and Contextual Factors on External Auditors' Whistle-blowing Intentions in Barbados. Phd Thesis, School Management, University of Bradford, United Kingdom.

Anwar, Z. (2003). Reviewing corporate excellent in the 21st century whistle blowing: Subversive spy or responsible corporate citizen? The Regional Conference on Agenda for $21^{\text {st }}$ century-Revitalising the Corporation, Kuala Lumpur, Malaysia, 29 September 2003.

Cecilia, F.L. (2013), Deciding to Blow the Whistle: How Individual and Organizational factor Influence the Reporting of Wrongdoing in the Federal Government, $\mathrm{PhD}$, Public Administration, Rutgers, The State University of Newark, New Jersey.

Chiu, R.K., (2003). Ethical judgment and whistleblowing intention: Examining the moderating role of locus of control, Journal of Business Ethics, 43(1), 65-74.

Coakes, S.J., Steed, L., \& Price, J. (2008). SPSS version 15.0 for windows: Analysis without Anguish. John Wiley \& Sons Australia Ltd., Australia.

Field, A. (2000). Discovering Statistics using SPSS for Windows Sage Publications. London

Ghani N.A, Galbreath, J. \& Evans R. (2012). Predicting Whistle-blowing Intention Among Supervisors in Malaysia. Journal of Global Management, 3(1),1-18.

Glazer, M.P. \& Glazer, P.M. (1987). Pathways to resistance: An ethical odyssey in Government in government in Industry. In M. lewis and J.L Miller (eds.), Research in Social problem and Public Policy, 4, 193-219, Greenwich City: JAI Press.

Hair, J., Black, W., Babin, B., Anderson, R., \& Tatham, R. (2010). Multivariate Data Analysis ( $7^{\text {th }}$ ed.). Uppersaddle River, N.J.: Pearson Prentice Hall.

Hassan, M.J. (2006). Making Malaysia corruption free. Kuala Lumpur, Malaysia: ISIS Malaysia.

Johnson, R. A., (2003). Whistle-Blowing: When it Works-And Why. Lynne Rienner Publishers, Boulder, United State.

Kanungo, R.N. (1982).Work Alienation: An Integrative Approch. New York: Praegar Publisher.

Lawler, E.E. (1992). The Ultimate Advantage: Creating the High Involvement Organization. San Francisco: Jossey-Bass. 
Lipman F.D. (2012). Whistle blowers: Incentives, Disincentives, and protection strategies. Hoboken: John \& Wiley Sons, Inc, 82-83.

Lodahl, T.M., \& Kejnar, M. (1965). The Definition and Measurement of Job Involvement. Journal of Applied Psychology, 49(1), 24-33.

Loewenthal, K.M. (2004). An Introduction to Psychological Tests and Scales (2 ${ }^{\text {nd }}$ ed.). Hove, UK: Psychology Press.

Miceli, M. P., \& Near, J. P. (2005). Standing up or standing by: What predicts blowing the whistle on organizational wrongdoing? Research in Personnel and Human Resources Management, 24, 95-136.

Miceli, M.P., \& Near, J.P. (1992). Blowing the whistle: The organizational \& legal implications for companies and employees. New York: Lexington Books.

Miceli, M.P., Near J.P., \& Dworkin, T.M. (2008). Whistle-blowing in Organizations. New York: Routledge.

Moberly, R.E. (2006). Sarbanes-Oxley's structural model to encourage corporate whistleblowers. Brigham Young University Law Review, 2005(5), 1107-1180.

Murray T.E. (2006). Peer Reporting of Workplace Deviance: The role of Organizational Justice and Social Contingency Factors. Dissertation submitted to the Tauro University International, College of Business Administration, Cypress, California, USA.

Near, J., Dworkin, T. \& Miceli, M. (1993). Explaining the Whistle-blowing process: suggestions from power theory and justice theory. Organization Science, 4(3), 393411.

Near, J.P. \& Miceli, M. P. (1985). Organizational Dissidence: The Case of Whistle-Blowing. Journal of Business Ethics, 4 (1), 1-16.

Ngui, C. Y. K. (2005). Fighting fraud. ProQuest Asian Business and Reference database, from ProQuest Asian Business and Reference database. Retrieved from http://www.umlib.um.edu.my/

Nunnally, J.C. (1978). Psychometric Theory (2 ${ }^{\text {nd }}$ ed.). New York: McGraw-Hill.

Pallant, J. (2007). SPSS Survival Manual (3 ${ }^{\text {rd }}$ ed.). New York: McGraw-Hill Education.

Park, H., Rehg, M. T., \& Lee, D. (2005). The Influence of Confucian Ethics and Collectivism on Whistleblowing Intentions: A study of South Korean public Employees. Journal of Business Ethics, 58(4),387-403.

Paullay, I.M., Alliger, G.M., \& Stone R.E.F. (1994). Construct validation of two instruments designed to measure job involvement and work centrality. Journal of Applied Psychology, 79(2), 224-228.

Ponemon, L.A.and Gabhart, D. (1994), Ethical reasoning research in accounting and auditing profession", in Rest, J. and Narvaez, D. (Eds), Moral Development in the Professions: Psychology and Applied Ethics, Erlbaum Associates, New Jersey.

PriceWaterHouse Corporation P.W.C (2014). Economic Crime: A threat to Business Globally. Global Economic Crime Surve, Price WaterHouse Corporation Publisher, Miami, U.S.

Read, W.J., \& Rama, D.V. (2003). Whistle-blowing to internal auditors. Managerial Auditing Journal, 18(5), 354-362.

Rice, A.J. (2015) Using scholarship on whistleblowing to inform peer ethics reporting. Professional Psychology: Research and Practice, 46(4), 298-305.

Rothschild J., \& Miethe T.D. (1999). Whistle-blower disclosures and management retaliation: the battle to control information about organization corruption. Work and Occupations, 26(1), 107-128. 
Rothwell, G.R., \& Baldwin, J. B. (2007a). Ethical Climate Theory, Whistleblowing, and the Code Of Silence in Police Agencies in the State of Georgia. Journal of Business Ethics, 70(4), 341-361.

Rothwell, G.R., \& Baldwin, J.B. (2006). Ethical Climates and Contextual Predictors of Whistle-Blowing. Review of Public Personnel Administration, 26(3), 216-244.

Said. J, Alam, M.M, \& Khalid. M.A. (2016). Relationship between good governance and integrity system: empirical study on the public sector of Malaysia. Humanomics, $32(2), 151-171$.

Seifert, D.L. (2006). The Influence of Organizational Justice on the perceived likelihood of whistle-blowing. Master Thesis, College of Business, Washington State University.

Shawver, T. \& Clement L.H. (2008). Whistleblowing: Factors That Contribute to Management Accountants Reporting Questionable Dilemmas. Management Accounting Quarterly, 9(2), 1-26.

Sims, R.L., \& Keenan, J.P. (1998). Predictors of external whistleblowing: Organizational and intrapersonal variables. Journal of Business Ethics, 17(4), 411-421.

Stikeleather, B.R. (2001). The Economic and Behavioral Effect of Offering Financial Rewards for Internal Whistle-Blowing. Phd thesis, University of Pittsburgh, Pennsylvania, U.S.

Tabachnick, B.G. \& Fidell L.S. (2001). Using Multivariate Statistics, $4^{\text {th }}$ Edition. Hedham Heights, MA,: Allyn \& Bacon.

Taylor, E.Z. \& Curtis, M. B. (2010). An Examination of the layers of workplace Influences in Ethical Juddments: Whistleblowing Likelihood and Perseverance in Public Accounting. Journal of Business Ethic, 9(1), 21-37.

Trevino, L. K., \& Weaver G.R. (2001). Organizational Justice and Ethics Program "FollowThrough": Influences on Employees' Harmful and Helpful Behavior. Business Ethics Quarterly, 11(4), 651-671.

Vadera, A.K., Aguilera, R.V., \& Caza, B. (2009). Making Sense of Whistle-Blowing's Antecedents: learning from Research on Identity and Ethics Programs. Business Ethics Quarterly, 19 (4), 553-586.

Vakola, M., \& Bouradas, D. (2005). Antecedents and consequences of organisational silence: An empirical investigation, Employee Relations, 27(5), 441-458.

Viswesvaran, C., Deshpande, S. P., \& Joseph, J. (1998). Job satisfaction as a function of top management support for ethical behavior: A study of Indian managers. Journal of Business Ethics, 17(4), 365-371.

\section{Appendix: List of variables}

\begin{tabular}{|c|c|c|}
\hline Dimensions & Factors & Loading \\
\hline \multirow{7}{*}{ 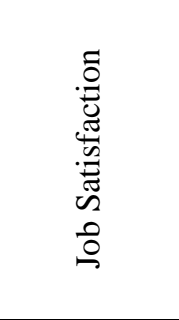 } & I am satisfied with the task given to me & 0.639 \\
\hline & All jobs done by me are appreciated by the upper level management & 0.797 \\
\hline & I feel motivated working in this organization & 0.843 \\
\hline & I would recommend my company as a place to work & 0.671 \\
\hline & Co-workers always support me in doing my job & 0.674 \\
\hline & The work I do is meaningful to me & 0.796 \\
\hline & In general, I am satisfied with my job & 0.686 \\
\hline \multirow{6}{*}{ 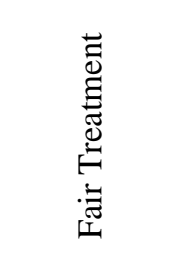 } & Career advancement & 0.760 \\
\hline & Awards & 0.743 \\
\hline & Training & 0.672 \\
\hline & Performance appraisals & 0.797 \\
\hline & Job assignment & 0.789 \\
\hline & Discipline & 0.677 \\
\hline
\end{tabular}


My work unit is able to recruit people with the right skills

\&े A spirit of cooperation and teamwork exist in my work unit

$\stackrel{D}{D}$ A spirit of cooperation and teamwork exist between my work unit and other work units workgroup disloyalty towards the organization wrongdoer

...I don't believe it is my duty to report the unethical behaviour of my fellow employees 